\title{
THE 'BIOLOGICAL ORIGAMI' OF TOOTH DEVELOPMENT REVEALED
}



Two articles published from King's College London's Dental Institute have revealed the cellular choreography that creates teeth, hair follicles and mammary glands during development in the womb. ${ }^{1,2}$
Professor Jeremy Green (pictured) from the Dental Institute has published two articles that show for the first time how cell rearrangements create the grooves and pits required to build teeth, hair follicles and mammary ducts. The work reveals the different cellular manoeuvres and shows that they rely on distinct genetic pathways.

The first paper investigates the creation of the tooth bud and the mechanisms driving stratification and invagination. The second papers looks at the invagination process in detail, and the migration of cells. Both represent part of a new era in developmental biology (embryology) that investigates how genes control cells to make tissues in the body. This goes beyond knowing the 'parts list' of genes in the genome and towards understanding the physical creation of tissues and organs.
Professor Green said: 'It's a kind of biological origami - tissues in the embryo must fold themselves into the structures that we see at birth. This is at the core of understanding how birth defects happen, and how we may one day be able to repair them with stem cells.'

1. Li J, Chatzeli L, Panousopoulou E, Tucker A
S, Green J B A. Epithelial stratification and
placode invagination are separable func-
tions in early morphogenesis of the molar
tooth. Development 2016; 143: $670-681$.
2. Panousopoulou E, Green J B A. Invagina-
tion of ectodermal placodes is driven by
cell intercalation-mediated contraction
of the suprabasal tissue canopy. PLoS Biol
2016; 14 : e1002405. doi: 10.1371/journal.
pbio.1002405.
pbio. 1002405.

\section{CONFERENCE REPORT}

\section{BRITISH UNDERGRADUATE DENTAL RESEARCH CONFERENCE 2016}

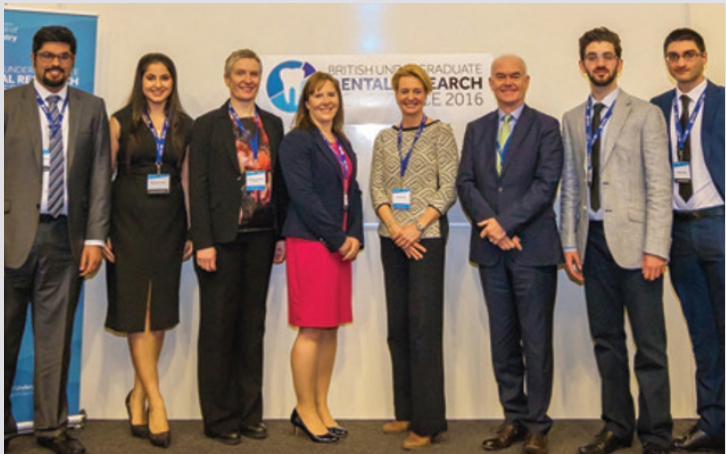

(I-r) Dental students Ahmad Alali and Simran Bains, Professor Anne-Marie Glenny, Dr Jennifer Taylor, Dr Sara Hurley, Professor Paul Coulthard, dental students Mohammad Jaberansari (founder, president and director) and Ismail Khalil (director)

Saturday 27 February 2016 saw the second British Undergraduate Dental Research Conference (BUDRC) take place at Manchester's University Place. This annual event is organised by the Manchester Undergraduate Dental Research Society (MUDRSOC) in association with the Manchester School of Dentistry. After the tremendous success of the first conference, it was clear there is a demand for such an event. The BUDRC is the first and largest undergraduate conference of its kind in the country.

The 2016 conference attracted over 200 delegates, $45 \%$ of whom were from outside of Manchester Dental School, and not just undergraduates but sixth formers, postgraduates, clinical staff and dental technology students. We are also proud to mention the international status of this event as students from Kuwait University visited.

After a busy registration period, the morning talks began featuring inspirational talks from renowned speakers including Professor Julian Yates, Dr
Jennifer Taylor, Professor AnneMarie Glenny and Professor Paul Coulthard, Dean of the Dental School. We were also privileged to have the presence of the Chief Dental Officer, Dr Sara Hurley, who spoke about evidence-based practice and the imperative role of research in making change, moving forward as a profession and improving the quality of patient care. The delegates found the talks to be stimulating and inspiring with many commenting on $\mathrm{Dr}$ Taylor's presentation style - how she brought research 'down to their level' and did not make it seem like this scary thing only professors take part in.

This year we were also able to offer workshops in eight disciplines. These included careers, interactive anterior tooth restoration seminars and even an exclusive hands-on endodontic access cavity workshop which gave delegates an opportunity to apply the skills using portable handpieces. Others included photography, suturing, orthodontics, research opportunities and interactive oral medicine workshops. Once again, the afternoon workshops were the favourite part of the day for delegates. It provided them with an opportunity to broaden their horizons with the many skills learnt and to see that life isn't just about teeth.

Arranging this conference is no small feat, with the sheer number of students in attendance, the reputation of speakers and workshop tutors involved. Professor Coulthard and especially Dr Hurley were greatly impressed by what was achieved by the organising committee: Mohammad Jaberansari, 5th Year BDS - Founder and President; Ismail Khalil, 3rd Year BDS, VicePresident \&t Co-Director; Ahmad Alali, 4th Year; Simran Bains 4th Year; Matthew Hughes 1st Year and Aneta Korobczuk 3rd Year.

There aren't many academic events for undergraduate students in this country, and the thought of a research conference on a Saturday morning seems absurd, but this conference proves there is a demand. The MUDRSOC will continue in its mission to raise students' awareness of dental research. We thank all of those who attended and look forward to seeing them again at the University of Manchester.

For more details, visit the website: www.mudrsoc.com.

By Mohammad Jaberansari and Ismail Khalil 